Indonesian Science Education Research
(ISER)

\title{
EVALUATION ANALYSIS OF DISTANCE LEARNING AT JUNIOR HIGH SCHOOLS IN SOUTH TAPANULI REGION
}

\author{
Siregar, A., Fauzia, D. S., and Salwa, G. \\ ${ }^{1}$ Department of Science Education, Faculty of Mathematics and Natural Science, Universitas Negeri \\ Medan \\ azwarsiregar@mhs.unimed.ac.id
}

Accepted: May $9^{\text {th }}, 2021$. Published: September $6^{\text {th }}, 2021$

\begin{abstract}
The pandemic COVID-19 has had many impacts on various aspects of people's lives in the world. One of the effects of the Covid-19 pandemic is on education around the world which has led to the closure of large schools, madrassas, universities and Islamic boarding schools. The spread of the virus which has spread very widely, the Indonesian government has issued social distancing and physical distancing policies to prevent more widespread transmission of the virus. So that the assessment and evaluation of learning in social distancing and physical distancing conditions carried out at home can use the remote assessment method. The purpose of writing this article is to find out how teachers evaluate students on distance learning during the pandemic COVID-19. The method used in this research was descriptive method. Descriptive method is a method used to describe, describe the phenomena that occur. This study used a quantitative approach. The quantitative approach aims to reveal something as it is (objective). The results that can be obtained from this study are distance learning teachers are very difficult to understand their students because during distance learning / offline the teacher can only provide a little material to students and the limited time given to the teacher during distance learning so that students also experience difficulties in receiving the lessons described by the teacher.
\end{abstract}

Keywords: Covid-19 Pandemic, Distance Learning Process, Student 


\section{Introduction}

The COVID-19 pandemic has had many impacts on various aspects of people's lives in the world. One of the effects of the Covid-19 pandemic is on education around the world which has led to the closure of large schools, madrassas, universities and Islamic boarding schools.

The spread of the virus which has spread very widely, the Indonesian government has issued social distancing and physical distancing policies to prevent more widespread transmission of the virus. This policy is implemented nationally so that it does not affect the affected areas, but also all areas that are not yet affected. This policy has also been implemented in the implementation of national education by issuing the Minister of Education and Culture Circular Number 3 of 2020 concerning the Prevention of COVID-19 in the Education Unit, and Circular Number 4 of 2020 concerning the Implementation of Education Policies in the Emergency of Coronavirus Disease (Covid-19). This step was taken to suppress and minimize the number of patients exposed to the virus (Kemdikbud, 2020).

Assessment and evaluation of learning in social distancing and physical distancing conditions carried out at home can use the remote assessment method. With current technological developments and advances, the application of distance assessment is very possible and facilitated in today's distance learning, especially with the existence of an internet network, teachers can use application media connected to the internet network to carry out assessments and evaluation of student learning outcomes online. The assessment can be in the form of quizzes, online tests, individual assignments, or other forms of online assessments using the internet. The selection of online assessment concept is seen as one of the concepts of learning that provides an opportunity for students to perform critical thinking processes (Muali et al., 2018). However, challenges will arise if this policy is implemented in areas with inadequate internet infrastructure and technology, such as in villages.
Problems that have problems in the implementation of distance education in the use of internet networks or problems such as; unequal access to technology and internet networks between big cities and regions; teacher competence in the use of learning applications; and how the teacher evaluates their students in distance learning.

In this case the researchers conducted survey activities about the methods teachers in South Tapanuli took to evaluate their students in distance learning or Distance Learning for junior high school levels during the Covid-19 pandemic. Researchers also want to find out how the types of assessment are most effective during distance learning.

\section{Research Method}

This research was conducted online through the Google Forms website or what is commonly called the Google Form which is distributed in the South Tapanuli Regency area which was implemented in 2020. This research was aimed at junior high school teachers in South Tapanuli to see how teachers were doing in Tapanuli. South to evaluate its students on distance learning during the Covid-19 pandemic.

The method used in this research is descriptive method. Descriptive method is a method used to describe, describe the phenomena that occur. This study uses a quantitative approach. The quantitative approach aims to reveal something as it is (objective).

Research conducted with a descriptive approach is not intended to test certain hypotheses, but only describes what it is about a variable. Quantitative research is presented in the form of statistics or figures, starting from the collection and interpretation of the data. Data collection techniques in this study were carried out by distributing questionnaire links to teachers in South Tapanuli for junior high school level. 


\section{Result}

Distance Leaming Media Omline (can be seleeted more than one) 100 Responden

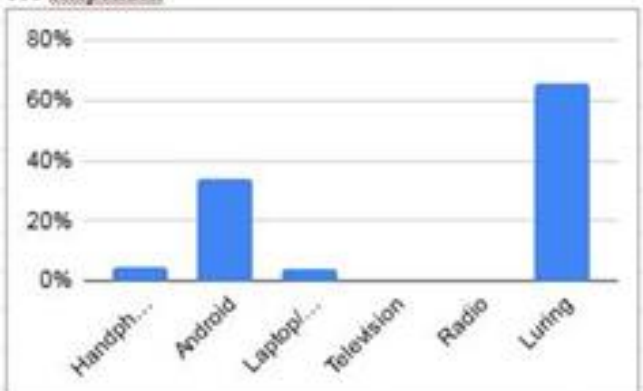

Figure 1. the Data on long-distance / offline learning media used by teachers in the teaching and learning process.

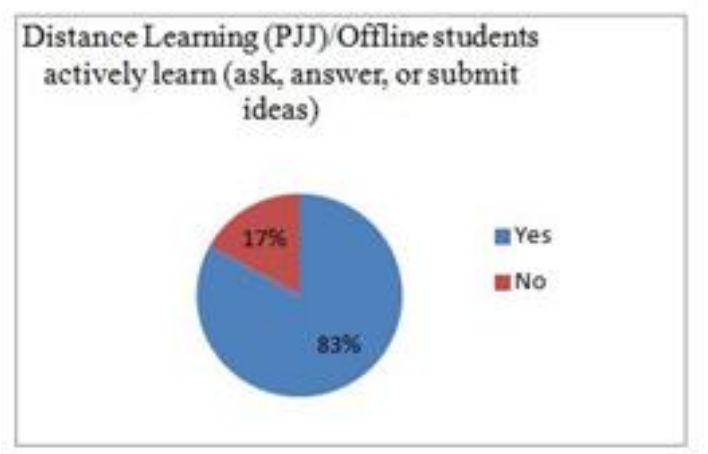

Figure 2. Data on student activity during $\mathrm{PJJ} /$ Offline.

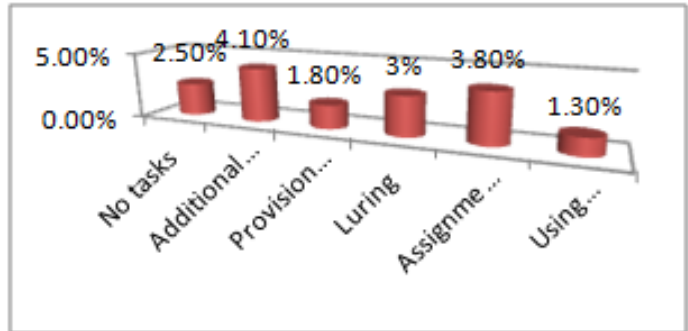

Figure 3. Dataon how teachers do in the Offline process if they don't have enough electronic media for teaching

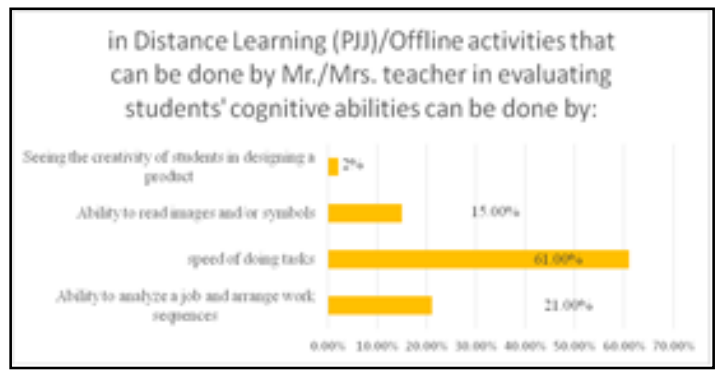

Figure 4. Data on the evaluation cognitive abilities students'in distance / offline Learning.

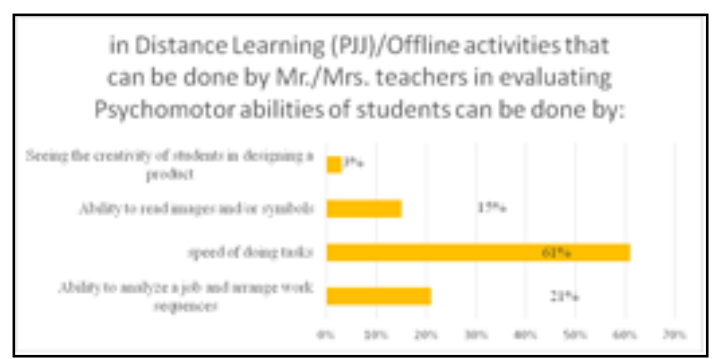

Figure 5. Data on students' psychomotor abilities in distance / offline learning.

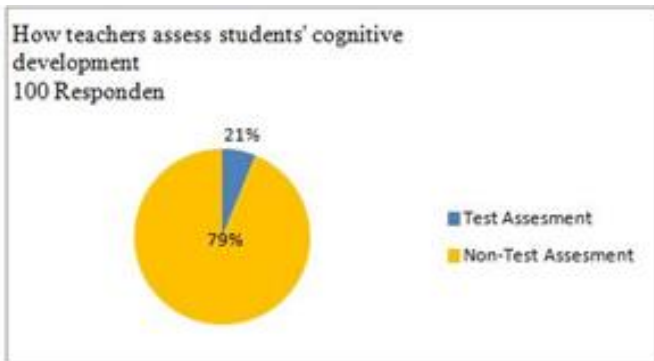

Figure 6. Data on student cognitive development.

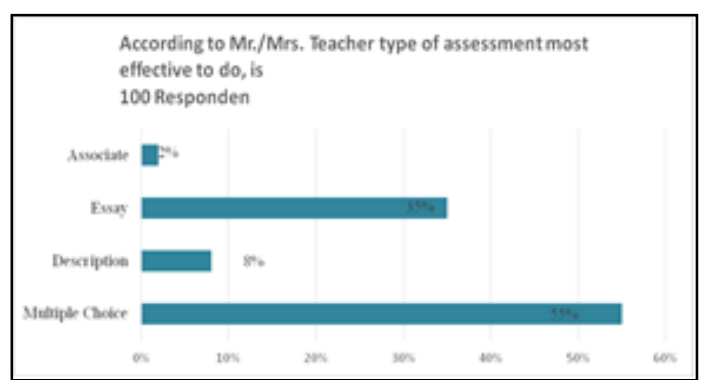

Figure 7. Data on the type of assessment that is most effectively carried out during distance / offline learning.

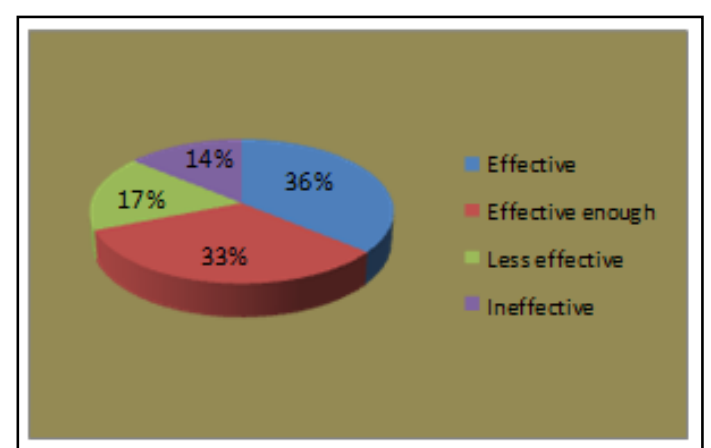

Figure 8. Data assessment is effectively carried out to determine the progress of student learning outcomes in PJJ / Offline. 


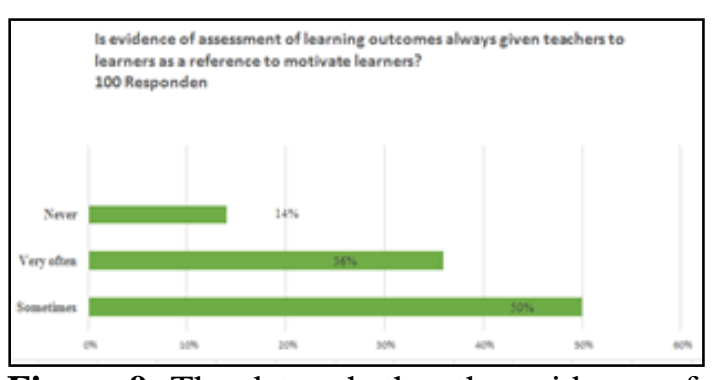

Figure 9. The data whether the evidence of evaluating learning outcomes by the teacher is always submitted again to students.

\section{Discussion}

Data obtained from the survey results regarding teacher assessment using Google Form are presented in graphical form. The following is an explanation of the data that has been obtained.

In the first graph, the media used the most by respondents was offline with a percentage of $66 \%$, then $34 \%$ for Android phones, $5 \%$ for regular cellphones, $4 \%$ for laptop media use, and the use of television and radio media which were not used by respondents in assessing students.

From the results of the survey that has been conducted, it can be concluded that students tend to be inactive in the learning process with a percentage of $83 \%$, and the active students are much less with a percentage of $17 \%$ active students. This makes teachers think more about choosing learning strategies so that students are more active. The survey results explained that the teacher prefers to give additional assignments to students with a percentage of $25 \%$, then give assignments to the class leader and then give them to other friends, this can help the teacher to condition the learning situation with a percentage of $23 \%$. Offline activities also help teachers in assessing students with a percentage of $18 \%$. The percentage of teachers who do not have a strategy is $15 \%$, the distribution of modules / material leaflets is $11 \%$, and uses electronic media by $8 \%$.

According to the survey results, the results of student learning with normal conditions with offline conditions have a very high impact because students are more uncontrolled during the teaching and learning process and students' lack of understanding of material that is not explained by the teacher. This makes the teacher assessment activities have an effectiveness level with a percentage of $36 \%$, teachers also feel that this activity is quite effective with a percentage of $33 \%$, $14 \%$ less effective, and $17 \%$ ineffective.

To find out the level of cognitive ability of the students the teacher gave a post test with a percentage of $62.6 \%$, a pretest of $40.4 \%, 21.2 \%$ of question and answer activities, and assignments with a percentage of $2 \%$. With cognitive development carried out by test assessment with a percentage of $79 \%$ and non-test assessment activities with a percentage of $21 \%$. The most effective types of assessment according to the teacher were essays with a percentage of $87 \%$, multiple choice of $82 \%$, description of $64 \%$, and matchmaking with a percentage of $17 \%$.

The activity of evaluating students' psychomotor abilities in Offline learning is carried out by the teacher by looking at the speed of doing tasks with a percentage of $71 \%$, the ability to analyze a work sequence with a percentage of $31 \%$, seeing the creativity of students with a percentage of $25 \%$, and the ability to read pictures or symbol at $11 \%$.

This is in line with the research results of Aristo H. et al. (2019) who found that the online teaching and learning process was ineffective based on the data, it appears that on average the responses of lecturers and students about the effectiveness of online lectures are less effective and ineffective, then only 33 out of 400 respondents felt effective in the online lecturing process. The various reasons given by the respondents will be explained in the discussion section.

Motivation for students to improve teaching and learning outcomes by teachers is more likely to be sometimes with a percentage of $50 \%$, teachers who often provide motivation with a percentage of $36 \%$, and teachers who never provide motivation with a percentage of $16 \%$. 


\section{Conclusion}

Based on the results of the research obtained from the results of data analysis:

During distance / offline learning, the teacher is very difficult to understand the students because at long / offline the teacher can only provide a small amount of material to students and the limited time given to students teachers at the time of Offline so that students also experience difficulties in receiving the lessons described by the teacher. It is hoped that this research can provide information for future researchers to produce more effective learning. We still hope for the development of our research.

\section{Reference}

Aji,S.H.R. 2020. Dampak Covid-19 pada Pendidikan di Indonesia: Sekolah, Ket erampilan, dan Proses Pembelajaran. Jurnal Sosial \& Budaya Syar-i. Vol. 7 No. 5. Hal: 395402.

Khaerunnisa.F. 2019. Evaluasi Penerapan Blended Learning Pada Pembelajaran Bahasa Arab di SMP IT Ibadurrah man: Studi Kasus di Kleas VII Akhwat. ALSUNIYAT: Jurnal Penelitian Bahasa, Sastra dan Budaya Arab. Vol. 2, No. 2, 95 108.

Khurniawan,W.A. dan Meidi A. 2019. Jarak Jauh di Sekolah Menengah Keju ruan. Vocational $131-8$.

Education Policy. Vol.1, No.

Hardinata, A., dkk. 2020. Survey On The Effectiveness Of Online Lecturres During Covid-19 Pandemic: Mehods and Difficulties. Jurnal Unimed. Vol. 2. No. 2. 7-12.

Muali, C., Islam, S., Bali, M. M. E. I., Hefniy, H., Baharun, H., Mundiri, A., ... Fauzi, A.
(2018). Free Online Learning

Based on Rich Internet

Applications; The Ex

perimentation of Critical

Thinking about Student

Learning Style. In Jour nal of Physics: Conference Series (Vol. 1114, pp. 1-6). Institute of Physics Publishing.

Prawiyogi,G.A. 2019. Efektifitas

Pembelajaran Jarak Jauh

Terhadap Pembelajaran

Siswa di SD IT Cendekia

Purwarta. Jurnal Pendidikan

Dasar. Vol.1, No.1 94-101.

Yustika, P. G., dkk. 2019. Masalah yang

Diha dapi Dunia Pendidikan

Dengan Tuto rial

Online: Sebuah Short Review.

TADBIR: Jurnal Studi

Manajemen Pendidikan. Vol.

3, No. 2, 187- 198. 